\title{
客家語のいわゆる「操作使役」文について 一北京語との対照を含めて一
}

\section{田中 智子}

(來京大学・院)

本文主要论析台湾南部( 美浓镇) 客家话中与普通话的“操作使役”相 对应的使役句式. 我们的主要观点是: (一)客家话所谓的 “操作使役” 根据 其前置词 “分(bun)” 和 “同(tung)” 的不同可以分成两个语义类型. 由 “同” 引导、并且句中动词由 “穿脱类” 动词充当的使役句接近于语言类型学中 的直接使役, 而由 “分(bun)” 所引导、同时句中动词由 “饮食类” 动词和 “视听类”动词充当的使役句则更接近于间接使役. (二)若以此为依据, 我们 认为普通话的 “操作使役” 句也可以分成这样两个语义类型. 由 “穿脱类” 动词构成的 “操作使役” 接近于直接使役, 而由 “㐸食类” 动词和“视听 类”动词构成的“操作使役”更接近于间接使役.

1.はじめに

2. 言語類型論の観点からみた使役

2.1. 使役という状況

2.2. 使役構文についての言語類型論

2.3. Shitabani and Pardeshi 2002 のパラメータ

3. 美渡客家語の使役構文

3.1. 美渡客家語の語旪的使役と形態的使役

3.2. 美濃客家語の分析的使役

4. 美渡客家語の「操作使役」文

5. 美浱客家語使役構文の意味的連続性

6. 北京語1)の「操作使役」文の再検討

7. おわりに（他の方言について）

1.はじめに

北京語の“给”には、次のように一種の使役文と考えることができるよ うな文がある。

（1）母亲给孩子穿鞋。（楊 1989,77） 
楊1989はこの文が日本語の操作使役に対応するものだと主張している。 日本語の操作使役とは、「子供に服を着せる」のようなものである。柴谷 1982はこのような文を、使役者が被使役者に直接作用を与える操作使役で ある、としている。(1)があらわしているのは、母親が子供に指示を与える という状況ではない。母親自身も子供に手を貸す、という動作を行なう状 況である。従って楊は(1)のような文を操作使役と考えるのである。

楊 1989, 79は、この「N1 给N2 VP」という構文が使役的意味をもつのは、 “看”や “听”のような動詞（以下本稿では [視聴覚類動詞]と呼ぶ）、“吃”, “喝”のような動詞 (以下本稿では [飲食類動詞] と呼ぶ)、“穿”，“脱”の ような動詞（以下本稿では [着脱類動詞] と呼ぶ）が述語に来る場合に限 ることも指摘している。

ところが、佐々木2002はこのように介詞 “给”を用いた使役文を操作使 役とは認めず、「授与使役」という新しい使役のカテゴリを導入している。 この両者で立場が違っているのは、言語類型論的な定義からみると北京語 の “给”を用いた使役文は操作使役の典型的な例だとはいいにくいからで はないかと思われる。

しかし、北京語を詳しく観察してみると、実は、共起する動詞の違いに よって、「操作使役」が表す状況が異なっていることがわかる。そして、あ るものは楊1989が主張するように言語類型論的な操作使役の典型に近く、 あるものは典型から少し離れる、といった状況を見せるのである。

北京語では、この種類の異なる使役をすべて 1 つのカテゴリにとらえ、 どれもが介詞 “给”を用いた粠文で表される。しかし、方言によってはこ れを異なる使役タイプを表すととらえ、それぞれ別の介詞で表す場合があ る。

客家語 ${ }^{2}$ には北京語のいわゆる「操作使役」に並行的な現象が見られる。 しかし客家語の場合は、北京語が「操作使役」であらわすような状況がす べてひとつの介詞を用いて表されるわけではない。客家語では共起する動 詞の意味の違い、ひいてはその使役があらわす状況の違いを “tung ${ }^{2}$ (同)” と、“bun'（分）”という 2 種類の介詞で表し分けるのである。

本稿では、客家語の使役文（特に北京語のいわゆる「操作使役」に対応 する使役文)を詳しく検討し、使役構文が表している使役の状況の違いが、 
介詞の違いなどによって明示的に現れていることを示す。

\section{2. 言語類型論の観点からみた使役}

\section{1. 使役という状況}

Song 2001, 275 は、使役構文は 2 つの出来事 (event) からなる巨視的な 状況 (macro-situation) を表していると定義した。その 2 つの出来事とは、 （I）使役者がほかの出来事 (引き起こされる出来事)を生じさせるために 何かを行うという出来事、そして、（II）使役者の行為の結果によって、被 使役者がある行為を行うか、状態の変化を経験するという出来事である。 Songは、使役の定義には、出来事のレベルと参加者のレベルという、2つ の異なるレベルも関係すると言っている。出来事のレベルというのは、出 来事をひきおこす側の事象と、引き起こされる側の出来事 (結果) の間の 関係をとらえるレベルである。参加者のレベルとは、使役者と被使役者と

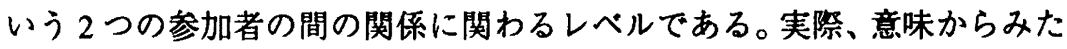
使役タイプの記述のほとんどは、この 2 つのレベルを中心に展開している (Song 2001, 275)。

Song 2001, 275-276 はさらに、この2つのレベルにおいては、それぞれ 使役タイプの対立があると主張する。まず、出来事のレベル（出来事を引 き起こす側の事象と、引き起こされる結果の関係) では、直接使役 (direct causation) の状況と間接使役 (indirect causation) の状況がありうる。そして、 参加者のレベル（使役者と被使役者の関係）では、操作使役 (manipulative causation) の状況と指示使役 (directive causation) の状況がありうる。以後、 類型論の観点から定義した manipulative causation を操作使役、中国語（北 京語）の分析において使われてきた操作使役という用語を「操作使役」と カッコをつけて記すことで両者を区別する。

ただし Song 2001 の主張では、出来事のレベルと参加者のレベルとは、 まったく独立しているわけではない。使役文の表す状況によっては、直接 使役的でかつ操作使役的である場合もありうる。

本稿で中心に取り上げる操作使役に関しては、すでにShibatani 1976で、 次のことが指摘されている：操作使役的な状況では、被使役者は意志的で ないとみなされる。使役者は、ある出来事を引き起こすためには、被使役 
者を物理的に操作しなければならない。たとえば英語の「John moved the chair.」という文が表しているのは、使役者が物理的に被使役者を操作す る、という状況である (Shibatani 1976, 31)。他方、被使役者に意志があり、 使役者が被使役者に指示を与えて動作を行わせるという使役的状況は、た とえば英語の「John made Bill move.」のように指示使役で表される (Shibatani 1976, 32)。

\section{2. 使役柾文についての言語類型論}

前節では使役という状況に関するパラメータをみた。本節では使役構文、 つまり使役文の形態に関する言語類型論を簡単に述べる。

使役構文は、言語類型論的な観点から、大きく次の 3 つにわけられる (Comrie 1989, 166-171 例は筆者による): (I )「語龟的使役」(例：日本語 の「たおす」、「動かす」、英語の「kill」など)、(II)「形態的使役」(日本語 の「倒れサセル」、など)、(四)「統語的（分析的）使役」(英語の「make him eat」中国語の「让他去」など)。

Song 2001, 276 によれば、先に挙げた 2 つのレベル（直接使役 vs. 間接 使役、操作使役 vs. 指示使役）が、さまざまな言語で上記の 3 つの使役構 文のタイプと関係があることが知られている。Song 2001 はまた、操作使 役や直接使役は語栄的使役で表される傾向が強いとも指摘している (Song 2001, 278)。操作使役が一般的には語整的使役で表されることが多いことは、 すでに Shibatani 1976, 31 で指摘されている。ただし Shibatani 1976は、操作 使役の状況を表す際に生産的な形式 (productive forms) を使うことが許され る場合があるとし、それは次の場合だと述べている：(あ）動詞がそれに対 応する語重的使役の形式を欠いているとき。または、(い)語專的使役構文 が許容する被使役者のタイブに制約があるとき(Shibatani 1976, 35)。なお、 Shibatani 1976, 35 のいう生産的な形式は、助動詞的な使役動詞を用いる形 式も、日本語のように接辞を用いる形式も、どちらをも含む。つまり、生産 的な形式とは、形態的使役も、統語的（分析的）使役も、いずれもありうる。

\subsection{Shibatani and Pardeshi 2002 のパラメータ}

ここでは、後の議論に関係する Shibatani and Pardeshi 2002 の考え方を紹 
介したい。

2.2で見たように、従来の類型論的使役構文の研究では使役楎文をその 形態によって分類した。そして直接使役、間接使役などの意味機能と使役 棈文の形態との関係が論じられてきた。Shibatani and Pardeshi 2002は、「直 接使役/間接使役」のようなおおざっばな分け方では定義があいまいであ るとし、意味を中心に使役構文を分析している。Shibatani and Pardeshi 2002 が着目したのは、引き起こされた事態に使役者と被使役者がそれぞれどの ように関わっているのか、という点である。直接使役の場合は、使役者は 動作主者であるのに対し、被使役者は受動者とみなすことができる。例え ば、“A kills P.”の場合、使役者 Aが動作主性を持つのに対し、Pは“kill”、 という行為の受動者である。Aの行為が直接ある結果を引き起こすのであ る。さらに、Aの行為 (“kill”) が行われる一連の過程と、それによってあ る結果が引き起こされる (P dies) という一連の過程は、同じ時間带 (T1)、 同じ空間 (L1)で起こる。Shibatani and Pardeshi 2002 は下記のような図式を 使ってこれを説明している。

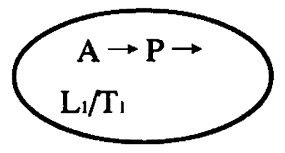

(Shibatani and Pardeshi 2002, 90)

一方、間接使役では、使役者と被使役者の両方が動作主性をもっている。 従って、使役者の意図がそのまま実行されるわけではない。まず使役者か ら被使役者に働きかけがなされてから、ある出来事が引き起こされる。つ まり、直接目的語のように使役者の行為からある出来事が引き起こされる までがひとまとまりなのではなく、少なくとも時間的に、そして場合に よっては、空間的に断絶がある。上記のことを図式化したのが次の図であ る。
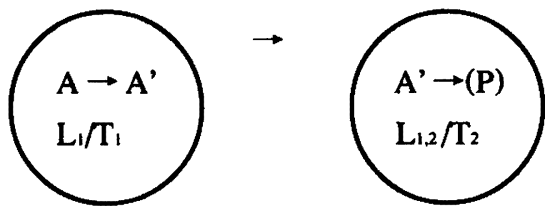

(Shibatani and Pardeshi 2002, 90) 
Shibatani and Pardeshi 2002はさらに直接使役と間接使役との間に中間的 な使役のカテゴリー、「sociative causative」を提案している。そして、直接 使役、sociative causative、間接使役がひとつの連続体を成していると考える。 sociative causative とは、使役者と被使役者が一緒に行動する状況を表すよ うな使役文で、使役者と被使役者は両方とも動作主となる。この点では間 接使役と同じである。そして多くの場合両者は同じ行動をとる。もうひと つの特徽は、使役者が行為を行う過程と被使役者が行為を行う過程は時間 的に重なることである。この点で直接使役の場合と似ている。Shibatani and Pardeshi 2002,100の考えでは、sociative causativeはさらに3つに下位分類 することができる。この分類の基準はやはり、ある出来事を引き起こす事 態とその出来事が引き起こされる、という事態が時間的空間的に重なって いるか、離れているか、という点である。

Shibatani and Pardeshi 2002 のパラメータは、美濃客家語や北京語の分析 にそのままあてはめられない部分もある。しかし、（I ）さまざまな使役構 文を連続体としてとらえる、という点と（II）使役者や被使役者と引き起 こされた出来事との関係がどのようになっているか、ということに着目す る点は美搌客家語や北京語の分析においても有効で、本稿では上記の 2 点 を踏まえて分析を行なう。

\section{3. 美湿客家語の使役権文}

本稿で扱うのは、高雄縣美涯鎮で話されている客家語の一方言である。 以下、この方言を美港客家語と記すことにする。美港客家語の使役構文は 語電的使役、形態的使役、統語的使役の 3 タイプがあると考えられる。

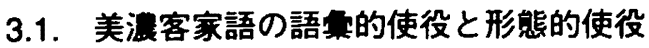

語象的使役はこれまでの調查では適当な例がほとんどみつかっていない。 強いて言えば、「zor 載せる（乗せる）」という動詞がある。

(2) $\mathrm{Fi}^{4} \mathrm{lim}^{2} \quad \mathrm{ki}^{2} \quad \mathrm{o}^{4} \mathrm{do}^{4} \mathrm{vai}^{3} \quad \mathrm{zni}^{4} \quad \mathrm{ngai}^{2} \quad \mathrm{hi}^{4} \quad \mathrm{hok}^{6} \mathrm{gau}^{3} \quad \mathrm{o}^{4}$ 人名乗る オートバイ乗せる私行く学校語気

【惠琳騎 odovai 去學校 $\square^{3)}$ 】

「恵琳はオートバイに乗って私を载せて学校まで行ったんだよ。」 
形態的使役については、Li and Thompson 1976 が北京語について「動詞 十補語」の形を使役としている。これに習えば、美濼客家語でも「钦詞十 補語」の形で使役を表す場合は数多く存在する。以下に一例を挙げる。

(3) cin'ziong ${ }^{1} \quad \mathrm{ge}^{4} \quad \mathrm{geu}^{3} \mathrm{e}^{8} \quad \mathrm{mak}^{5} \quad \mathrm{si}^{2} \quad \mathrm{e}^{8} \quad \mathrm{ne}^{2}$.

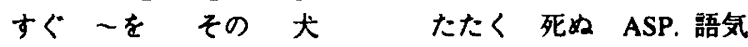

【就將該狗仔 $\square$ 死 $\square$ 呢】

(ASP.:aspect marker)

「すぐその犬を(棒で)叨き殺してしまったよ。」(昔話の談話资料から)

\section{2. 美㴤客家語の分析的使役}

分析的使役は次のような構文で表される。

<使役者 介詞被使役者 V (NP) >

このときの介詞には、bun ${ }^{1}$ (分)、hem ${ }^{1}$ (喊)、 $\operatorname{von}^{3}$ (口)、 sii $^{3}$ (使)、 tung ${ }^{2}$ （同）がある（以下それぞれ BUN, HEM, VON, SII, TUNG と記す。）。ただ し、今回例文の確認をしていただいた 30 代の話者の中にはSIIを「あまり 使わない」と報告する人もおり、今回の分析では取り上げないことにする。

また、介詞 BUNに限っては、下記の構文でも使われることがわかって いる。この構文については 4 節で詳しく述べる。

\section{<使役者 V 1 (NP) BUN 被使役者 V 2 >}

BUN, HEM, VON は動詞として用いられることも確認できており、bun ${ }^{1}$ は与える、hem 1、von ${ }^{3}$ は呼ぶ、などの意味で使われる。TUNGは美浱では 慣用語的な一部の例を除き、動詞としての用法は確認していない。もっぱ ら同伴者、動作の相手、受益者等を標示する介詞として用いられる（田中 2001b, 85)。

それぞれの介詞によって表される使役の状況の違いについては、今のと ころ次のような傾向がわかっている。

Song 2001 の二元的なパラメータでは、大体 HEM, VON, BUN は指示使 役、TUNGは操作使役といえる。しかしこのパラメータだけでは、細かい 意味の違いを十分にとらえることができない。HEM, VONを用いた場合は 主として使役者が被使役者に口頭で指示を与えてある行為をさせるような 指示使役の状況を表す。BUNを用いた場合は使役者が被使役者に許可を与 えたり、あるいは被使役者が行動を起こすのを妨げない、というような許 
容使役の状況を表す。TUNG を用いた場合は、一種の操作使役をあらわす と考えられる。

以下に例を挙げる。(4)，(6)は VON, HEM を用いた使役粠文の例、(5), (7) は BUN を用いた使役文の例でインフォーマントへの対面調査で得られた もの、(8)は TUNG を用いた使役粪文の実例である。

(4) ge tu $^{3} \mathrm{fi}^{3} \operatorname{teu}^{2} \mathrm{e}^{3}$ von ${ }^{3} / \mathrm{hem}^{1} \mathrm{gia}^{1} \mathrm{pu}^{4} \mathrm{ha}^{4} \mathrm{hi}^{4}$ teu $^{1}$ dung ${ }^{1} \mathrm{si}^{1}$. その 土匪の頭 VON/HEM 彼の 部下 行く盜む品物

【該個土匪頭子 $\square /$ 喊 其部下去偷東西。】 [A/B]=「A または B 「その土匪のかしらは彼の部下に（指示して）品物を盗ませた。」

(5) ge tu ${ }^{3} f^{3} \operatorname{teu}^{2} e^{8}$ bun ${ }^{1} g^{1 a^{1}}$ putha $^{4} h^{4}$ teu $^{1}$ dung ${ }^{1} \mathbf{s i}^{1}$. その土匪の頭 BUN 彼の 部下 行く盗む品物

【該個土匪頭子分其部下去偷東西。】

「その土匪のかしらは彼の部下に(盗みたがっているから許可して)品 物を盜ませた。」

(6) $a^{1} \mathrm{me}^{1} \quad$ von $^{8} \mathbf{h e m}^{1} \quad \mathrm{a}^{1} \mathrm{moi}^{2} \quad \mathrm{hi}^{4} \quad$ go $^{1} \mathrm{hiong}^{2}$. 母親 VON/HEM 阿梅 行く 高雄

【阿姆口/喊阿梅去高雄。】

「(何か用事があるなどして)お母さんは阿梅に命じて高雄に行かせた。」

(7) $\mathbf{a}^{1} \mathbf{m e}^{1}$

母親 bun $^{1} \mathbf{a}^{1} \mathbf{m o i}^{2} \quad$ hi $^{4} \quad$ golhiong $^{2}$.

BUN 阿梅 行く 高雄

【阿姆分阿梅去高雄。】

「母親は（阿梅が行きたがったので許して）阿梅を高雄に行かせた。」

(8) tung ${ }^{2} \quad$ ngai $^{2}$ zok $^{5}$ sam $^{1}$

TUNG 私着万(着せる) 服

【同我著衫。】

「私に服（上着）を着せて。」（体が不自由なお年より（80代）が筆者 に言った実例）

例文(4)，(6)はVON, HEMのいずれかの介詞を用いることができる。(8)は、 もしTUNGをBUNにかえると、「私が上着を着ることを許可してくれ」と いう意味になってしまう。

なお、すでに述べたように美浱客家語では、TUNGは次のように受益者 
などを示す標識としても用いられる。

(9) gia ${ }^{1} \quad \mathrm{ba}^{1}$ tung $^{2} \mathrm{gi}^{2} \quad \mathrm{zo}^{4} \quad \mathrm{ia}^{3} \mathrm{ge}^{4} \mathrm{vuk}^{5} \mathrm{ge}^{3}$ 彼/彼女の父 TUNG 彼/彼女作るこの詞家

【其爸同佢做逭個屋 $\square$ 】

「彼女のお父さんは彼女にこの家を建ててやったんです。」

従って下記のように一種の操作使役を表す文は受益桠文と同じ構造をして いるといえる。

(10) $a^{1} \mathrm{me}^{1}$ tung $^{2} \operatorname{se}^{4}$ gin $^{2} \mathrm{ne}^{8} \quad \mathrm{zok}^{5} \quad \operatorname{sam}^{1} \mathrm{fu}^{4}$. 母親 TUNG 子供着る(着せる) 服

【阿姆同細人仔著衫褌。】「母親は子供に服を着せた。」

しかし、(9)であくまでも「彼女」が一連の出来事の傍観者的存在である のに対し、(10)では「母親が子供に働きかけた結果、子供が服を着るという 状況が生じた」わけで、これは一種の使役的状況であるといってもよい。 日本語でも「てもらう」が使役の状況を表すことが指摘されており（奥津・ 徐 1982, 98 益岡 2001,28)、美瀑客家語で受益楎文が使役的状況を表すと 考えても不自然ではない。本稿では受益構文の形をした(8)、(10)のような 文も一種の使役文として扱うことにする。

本節では美漕客家語の使役構文について概観した。次の 4 節では、美浱 客家語の使役構文のうち、北京語のいわゆる「操作使役文」に対応する構 文を取り上げて議論を行なう。

\section{4. 美浽客家語の「操作使役」文}

「はじめに」で述べたように北京語のいわゆる操作使役は共起する動詞に 制約がある。楊 1989,79で指摘されている [梘聴覚類動詞]、[飲食類動詞]、 [着脱類動詞］のほかにも「洗澡」、上(电视)」、「丢脸」、「坐」など共起可 能な動詞もある4)。しかしコーパスを見てみると、やはり [視聴覚類動詞]、 [飲食類動詞] と共起する割合は他の動詞と比べて多い5)。また意味の面で は、「使役者は被使役者に何かを授与するか、直接的な動きかけを行うこと によって、動作·行為を引き起こす。という特徽があると指摘されている （佐々木 2002, 181）。

本節では美浱客家語の使役文の中で[視聴覚類動詞]、[飲食類動詞]、[着 
脱類動詞]と共起し、上記に挙げたような意味特徴をもつ使役文を北京語 との比較の対象とする。

美灌客家語では、[着脱類動詞]と共起する場合には介詞 TUNGが使わ れるが、[飲食類動詞］や[視聴覚類動詞］と共起する場合には、許可の意 味を表す使役文と同様に介詞 BUN が用いられる。

以下にまず [着脱類動詞] と共起する場合の例文をあげる。なお、美濃 客家語では「操作使役」を表す [着脱類動詞]には、「着る」のほかに「tot 脱ぐ」「da`かぶる、(手袋を) はめる」、「get (带、ベルトを) 締める」、 $\left\lceil\mathrm{ge}^{3}\right.$ (帯、ベルトを) 解く」などがある。

(11) $a^{1} \mathrm{e}^{1}$ tung ${ }^{2}$ setngin' $^{2} \mathrm{e}^{3} \quad \operatorname{tot}^{5} \operatorname{sam}^{1} \mathrm{fu}^{4}$. 母親 TUNG 子供脱ぐ 服

【阿姆同細人仔著衫褳】「お母さんは子供から服を脱がせる。」

(12) $a^{1} \mathrm{me}^{1}$ tung ${ }^{2}$ se'ngin $^{2} \mathrm{ne}^{3}$ dai $^{4} \mathrm{mo}^{4} \mathrm{e}^{3}$. 母親 TUNG 子供 加万帽子

【阿姆同細人仔戴帽仔】「お母さんは子供に帽子をかぶせる。」

次に、共起する動詞が [飲食類動詞] [ 視聴覚類動詞] の場合を挙げる。

(13) ngai' zongl fan' bun $^{1}$ se'ngin' $^{2}$ e $^{8}$ siit $^{6}$ het $^{5} e^{3}$ 私よそる 飯 BUN 子供食べる 終わる Asp.

ian $^{2}$ loi $^{2}$ hi42.

そして 来る 行く

【我張飯分細人仔食 $\square \square$ 然來去】

「(小さい) 子供にご飯を食べさせてから行きます。」

(14) ngai ${ }^{2}$ pau $^{4}$ valiung $^{2} \mathbf{c a}^{2}$ bun $^{1} \mathbf{n g}^{2} \quad \lim ^{2}{ }^{6)}$

私いれる 烏龍茶 BUN あなた 饮む

【我泡烏龍茶分你 $\square$ 】

「(お客に対して）あなたに烏龍茶を入れてあげます。」

(15) ngai $^{2}$ gong $^{3}$ gu$^{4}$ sii $^{4}$ bun $^{1} \mathbf{k i}^{3}$ ngien $^{2} \sin ^{1}$ sang $^{1}$ tang1. 私言う 話 BUN 人名開く

【我講話分啟元先生聽】「私は㤵元さんにお話（昔話）をしてあげた。」

(16) bai $^{4}$ tok $^{5} \quad$ ng $^{2} \quad$ na $^{1} \quad$ loi $^{2} \quad$ bun $^{1}$ ngai $^{2}$ kon $^{4}$. すみません あなた 取る 来る BUN 私 見る 
【拜託你拿來分我看】

「(遠くにある品物を見たいので店員に頼むとき)すみません、とって 見せてください。」

例(13)-(16)で見るように、共起する動詞が[飲食類動詞]ゃ[視聴覚類 動詞]の場合は、「BUN 被使役者 V2」の前に動詞句をおいて、<使役者 V1 (NP) BUN 被使役者 V2 >とする語順のほうが比較的好まれるようである。 インフォーマントに日本語の文を訳してもらったときは、まずこの構文の 形で出てくることが多い。ただし、く使役者 BUN 被使役者 V(NP)>とい う語順と比べて、語順の違いが許容度に反映するのかどうかを明らかにす るためには、今後さらに大量のコーパスを集めて分析する必要がある。

<使役者V1 (NP) BUN 被使役者V2>という構文が好まれる理由として 次のようなことが考えられる。佐々木 2002, 184-185 は福州語の「授与使 役」(本稿のいわゆる「操作使役」) の肯定形ではやはり<使役者 V1 (NP) 乞（与える）被使役者 $\mathrm{V} 2>$ というように「使役者が行なった授与行為を 具体的に明示しなければならない。」と述べている。美瀑客家語の介詞 BUNを用いた「操作使役」文も、動詞 bun' ${ }^{1}$ もつ「給与」の意味から、使 役者から被使役者へのものの授与が想定される。そのため、<BUN 被使 役者 $\mathrm{V} 2>$ 前にく使役者V1 (NP) >という部分があることで、与えられる モノが特定化・具体化され、より自然な文になるのではないだろうか。

以上、美浱客家語では共起する動詞の種類の違いによって介詞を使い分 けることを述べた。次になぜこのように介詞を使い分けるのかということ を考えていきたい。

筆者の主張は、以下のようである。[着脱類動詞]と共起する「操作使 役」文と [飲食類動詞]や[視聴覚類動詞]と共起する「操作使役」文と は、実はあらわす使役の状況に違いがあり、美濃客家語ではその違いに着 目して2つのカテゴリーに分けているのである7゙。2.3で紹介したShibatanai and Pardeshi 2002 のパラメータを踏まえてその違いを考える。

[飲食類動詞]や[視聴覚類動詞］と共起する「操作使役」文は、もし使 役者が食べ物や飲み物を口のそばまで持っていったとしても、やはり最終 的には被使役者が自分で物を咀噂しなければ、被使役者が物を食べる、飲 むといった事態は成立しない。見る、聞く、といった事態に関しても同様 
である。従って、弱いかもしれないが、被使役者の動作主性は、あるといっ てよい。また、時間的空間的にも使役者の行為（食べさせる、飲ませる、見 せる、聞かせる）とそれによって引き起こされた事態（被使役者が食べる （または）飲む（または）見る（または）聞く）時間と場所は重なっている といえる。この点で[飲食類動詞]や [視聴覚類動詞]と共起する「操作使役」 文は、Shibatani and Pardeshi 2002 の提案する “sociative causative”に似て いる。

一方、[着脱類動詞]と共起する「操作使役」文が上記の「操作使役」文 と異なる点は、被使役者の動作主性がほとんどない、といってよいことに ある。例えば被使役者が体の不自由なお年奇りであれば、まったく何も行 動せずにされるがままに服を着せられる、という状況が思い浮かが。この 点で [着脱類動詞]と共起する「操作使役」文が示す使役の状況はむしろ 直接使役が表す状況に近いということができるだろう。時間的、空間的に みてももちろん使役者の行為とそれによって引き起こされた事態の間には 重なりが見られる。

以上に述べたことをまとめると次のようになる。

美搌客家語の「操作使役」文

\begin{tabular}{|l|l|l|l|l|}
\hline 使う介詞 & 共起する動詞 & $\begin{array}{l}\text { 使役者の } \\
\text { 動作主性 }\end{array}$ & $\begin{array}{l}\text { 被使役者の } \\
\text { 動作主性 }\end{array}$ & $\begin{array}{l}\text { 使役者の行為と引 } \\
\text { き起こされた事態 } \\
\text { の時間的空間的重 } \\
\text { なり }\end{array}$ \\
\hline TUNG & [着脱類動詞] & $\bigcirc$ & $\times$ & 重なる \\
\hline BUN & [飲食類動詞] & $\bigcirc$ & $\bigcirc($ 弱い) & 重なる \\
\hline BUN & [視聴覚類動詞] & $\bigcirc$ & $\bigcirc($ 弱い) & 重なる \\
\hline
\end{tabular}

\section{5. 美湍客家語使役權文の意味的連続性}

本節では 3 節と 4 節の内容を踏まえ、美浱客家語使役構文の意味的連続 性について考察する。

類型論で論じられているように、語策的使役や形態的使役は直接使役を 
表す傾向にある。例はあまり挙げなかったが、美灌客家語でも例文(2)、(3) のような使役棬文は次の点で直接使役を表すといってよいだろう。（Ｉ）使 役者が功作主性を示すのに対し、被使役者の動作主性は問われないという 点、(II) 使役者の行為と引き起こされた事態が時間的空間的に重なってい る。

次に意味的に直接使役に近いのは、4節で述べたように「TUNG + [着脱 類動詞]」で表される使役表現である。「BUN + [飲食類動詞] / [視聴覚類勤 詞]」はやや間接使役に近くなる。

「BUN + [飲食類動詞] / [梘聴覚類動詞]」で表される使役棈文は、相手に 許可を与えるような使役の状況を表す「BUN+一般動詞」とあいまいな例も 存在する。

(17) bun ${ }^{1}$ hok $^{6}$ sang $^{1} \mathrm{e}^{3}$ siit $^{6} \mathrm{me}^{2}$.

BUN 学生 食べる 〜ではない

【分學生仔食呣】「学生に食べさせるんでしょう？」

(18) $\mathrm{ng}^{2} \quad k^{4}$, bun' ${ }^{1} \mathrm{ng}^{2} \quad k^{4}$. あなた 見る BUN あなた 見る

【你看，分你看】「(あなた）見なさい、あなたに見せてあげる。」 上の 2 つの文はインフォーマント調査によるものではなく、筆者が美瀑で 生活しているときに得た実例である。(17)はあるイベントで弁当が余った ときに 1 人の人が言った言葉で、担当の先生などが学生のところにもって いって与えて食べさせたとすればやや「操作使役」的な色合いがあるし、 学生に勝手に持っていかせて食べさせるのなら許可の意味が強くなる。(18) はある人が筆者に写真を手渡しながら言った言葉で、その人が実際に手渡 すという行動で簕者に傎きかけているとすれば「操作使役」的であり、単 に筆者に写真を見る許可を与えているともいえる。

「BUN +一般動詞」はさらに間接使役に近くなる。例えば、

( $5=$ 再揭) $\mathrm{ge}^{4} \mathrm{ge}^{4} \mathrm{tu}^{3} \mathrm{f}^{8} \mathrm{teu}^{2} \mathrm{e}^{3}$ bun $^{1} \mathrm{gia}^{1} \mathrm{pu}^{4} \mathrm{ha}^{4}$

その 土匪の頭 BUN 彼の 部下

hi4 $^{4}$ teu $^{1}$ dung ${ }^{1} \mathbf{s i}^{1}$.

行く 盗む品物

「その土匪のかしらは彼の部下に(盗みたがっているから許可して)品 
物を盗ませた。」

のような文では、土匪の頭が部下に許可を与えるという事態とその結果部 下が物を盜むという事態が起こる間には時間的 (空間的) ギャッブが存在 する。また使役者と被使役者には両方ともはっきりとした動作主性が見ら れる。

介詞VONやHEMについても、同様に使役者と被使役者の両方に動作主 性があることと、使役者の行為と引き起こされる出来事の間には時間的 (空間的) ギャッブが認められる。

以上を整理すると次のような図にまとめることができる。

美港客家語使役構文の意味的連続性

直接使役 $\rightarrow$ 間接使役

\section{語重的}

形態的

分析的 (TUNG + [着脱類動詞 ])

\begin{tabular}{|l|}
\hline 分析的 (BUN + [飲食類動詞 $])$ \\
\hline 分析的 (BUN +[梘聴覚類動詞 $])$ \\
\hline
\end{tabular}

BUN +一般動詞

VON, HEM

\section{6. 北京語の「操作使役」文の再検討}

本節では美港客家語の分析をふまえ、北京語の「操作使役」文について 検討する。

美浱客家語では、いわゆる「操作使役」文がその表す使役の状況によって 少なくとも2つのカテコリに分けられることを指摘した。美漉客家語では その 2 つのカテコリはそれぞれ別の介詞 (BUN, TUNG)を用いて表される。 北京語ではいわゆる「操作使役」文はすべて介詞「给」を用いて表す。し かし詳しく見てみると、やはり美港客家語と同様に共起する動詞によって 表す使役の状況が異なっていることがわかる。

（1＝再揭）母亲给孩子穿鞋。（楊 1989,77） 
上記の文のように[着脱類動詞]と共起する場合は、北京語でも被使役者 の動作主性はほとんどないといってよい（楊 1989, 77 田中 2001a, 144146)。今回調ベたコーパス（老舎作品 2 編、及び王朔作品 2 編。後に詳述。) の中にも被使役者が死人であるという例があり、この場合被使役者に動作 主性があるというのは明らかに不可能である。

（19）青年无可如何的把衣服给 [死户] 穿上, 抱起她来。

（老舍《四世同堂》[]は筆者）

一方、[飲食類動詞]や [視聴覚類動詞]を用いた「操作使役」文は、美 浱客家語の場合と同椂に被使役者にはある程度の動作主性があると考えら れる。

また、[着脱類動詞］と共起する場合も [飲食類動詞］や [視聴覚類動 詞]と共起する場合も、使役者の锶きかけとそれによって引き起こされた 被使役者の行為との間には時間的、空間的重なりがあると考えられる。

上記に述べた事柄を美渻客家語に習い、下記の図のようにまとめる。 北京語「操作使役」(“给”使役) 楎文の意味的連続性

直接使役 $\rightarrow$ 間接使役

“给” + [着脱類動詞 $]$

$$
\begin{array}{|l|}
\hline \text { “给” }+ \text { [飲食類動詞 }] \\
\hline \text { “给” }+ \text { [視聴覚類動詞 }] \\
\hline
\end{array}
$$$$
\text { “叫”, “让" }
$$

図には示していないが、[着脱類動詞]、[飲食類動詞]、[視聴覚類動詞] 以外の動詞と“给”が共起する場合は、より文法化が進んだ段階として“叫” や“让”を用いた使役に近い位置にあると考えられる。

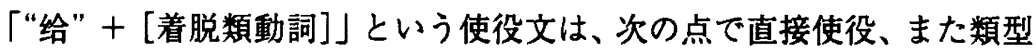
論で言う操作使役に近いものであるといえる。(I)被使役者に動作主性が なく、使役者はある出来事を引き起こすために、被使役者を物理的に操作 する必要がある。（II）2節で述べたように、言語類型論でいう操作使役は、 一般的には 1 つの動詞によって表されるものをいう。しかし、北京語では 動詞がそれに対応する語杂的使役の形式を欠いており（動詞一語で「着せ 
る」、脱がせる」という状況を表すことはできない)、操作使役を表すため に分析的使役という生産的な形式を使うことはおかしくない。

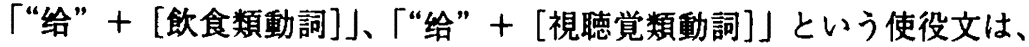
次の点で操作使役の典型から離れる。つまり、使役者は被使役者に何かを 与えるかもしれないが、飲む、食べる、見る、聞く、などの行為を行うの はあくまでも被使役者である。よって使役者が被使役者に直接物理的作用 を加えるとはいいにくい。

ところで、美泿客家語は介詞の違いという形式の違いで 2 つのカテゴ リーを分けているが、北京語でも美瀑客家語と同様に形式的に 2 つのカテ コリーを分けている可能性がある。

老舎の作品 2 編 《四世同堂》《骆驼样子》(計約 76.8 万字) と王朔の作品 2 編 《看上去很美》《我是你爸爸》（計約 43.8 万字）を調べたところ、[着脱 類動詞]と共起する「操作使役」文と [飲食類動詞]p [視聴覚類動詞] と共起する「操作使役」文では、好まれる構文に傾向の違いが見えた。

データは次のように採取した。コーパス中から介詞“给”と動詞“穿”、 “脱”、“看 (看见，看看)”、“听”、“吃”、“喝”が共起する場合を抽出し、 さらにその中で使役を表していると思う文を抜き出した。次に“都说给瑞 宣听”のように“v+ “给”という複合語になっているもの、“给产妇吃的 点心”のように関係節の中に入っているものをのぞいた。この結果、分析 の対象となった使役文は、老舎の作品で27例、王朔の作品で 19例あった。 また、最終的には、共起する動詞が “脱”、“听”であるような例の数は 0 になった。

このうち、「操作使役」<使役者＋“给”＋被使役者＋VP>の前に使役 者の何らかの動作を示す動詞句がくる場合 (例:“勾一锅䉼给大家吃。”) と ない場合（例：“给妞子吃，”）に分けて整理したのが下記の表である。

\begin{tabular}{|c|l|l|l|l|l|l|l|l|}
\hline \multirow{2}{*}{ 作家 } & 穿 & \multicolumn{1}{|l|}{ 看 } & \multicolumn{2}{l|}{ 吃 } & 喝 & 計 \\
\cline { 2 - 10 } & $\mathrm{V}$ & $\phi$ & $\mathrm{V}$ & $\phi$ & $\mathrm{V}$ & $\phi$ & $\mathrm{V}$ & - \\
\hline 老 & 1 & 4 & 3 & 7 & 10 & 2 & 1 & 26 \\
\hline 王 & 1 & 0 & 9 & 4 & 1 & 4 & 0 & 19 \\
\hline 計 & 2 & 4 & 12 & 11 & 11 & 6 & 1 & 45 \\
& $(33 \%)$ & $(67 \%)$ & $(52 \%)$ & $(48 \%)$ & $(65 \%)$ & $(35 \%)$ & $(100 \%)$ & \\
\hline
\end{tabular}


前に動詞句がくる場合を「V」と記し、前に動詞句が来ない場合を「申」と 記す。

老：《四世同堂》《骆驼祥子》王 : 《看上去很美》《我是你爸爸》

表を見ると、“穿”では前に使役者の行為を表す動詞句が来ない割合が多 いのに対し、“吃”，“喝”では逆に動詞句がくる割合が多くなっている。“看” に関してはどちらの場合もほとんど変わらずはっきりとした違いは出てこ ない。

また、北京出身の母語話者に聞いてみたところ、次のような内省が得ら れた。例えば、母親が手が離せないので、母に靴をはかせてあげるような 場合、“我给你穿鞋。”という言い方は自然であるが、母親にご飯を食べさ せてあげようとして、“我给你吃饭。という言い方はあまりしない。もし 言うとすれば“我做饭给你吃。”のようにやはり“给” の前に「V(NP)」と いう句がくるほうがよいとのことであった。ところが、相手が自分で手を 使えないお年寄りで、使役者がその口元まで食べ物を持って行き食べさせ てあげるという状況ならば“现在我就给你吃饭。”のように言うことができ るそうである。このようにデータや母語話者の内省から、共起する動詞に よって異なる「操作使役」文が表す状況の違いが構文の違いに反映してい る可能性は否めない。“给”を用いた使役の例は数が少ないため、今後さら に多くのデータを集め、この仮定を証明するさらに強い根抛を示したい。

\section{7. おわりに（他の方言について）}

今回は美灌客家語と北京語の状況について述べた。しかし、使役の表す 状況によって介詞を使いけるという方言は、美浱客家語に限らず他の方言 にもあるようである。例えば、上海語では [着脱類動詞]のときは “我告/ 脱儿子穿衣裳。”「私は（服を手に持って）子供に服を着せた」のように、 “告”か “脱”を用い、[視聴覚類動詞]や[飲食類動詞］のときは“我拨 儿子看电视”「私は子供にテレビを見せた」。や “我拨儿子喝水”「私は子供 に水を飲ませた」のように“拨”を使うそうである。この“拔”は「与え る」という意味を持つ動詞と同じ形をしている（楊凱栄先生私信）。

刘 2003 は北部点語の介詞 “搭”、“帮”の文法化の過程について論じた論 文である。この “搭”、“帮”は、いずれも同伴者を標示したり受益者を標 
示したりする用法がある。刘 2003 は、先の例で挙げた介詞 “脱” は上海語 の “搭”が音変化したもので、“告”は“搭”の同義語であるとしている (刘 2003, 127)。

以上のことから、上海語は（I） [着脱類動詞］の使役文では同伴者標識、 受益者標識と同じ介詞が使われる。（II）[視聴覚類動詞］や [飲食類動詞］と 共起するときは「与える」という意味を持つ動詞と同じ形をした介詞が使 われる。この 2 つの点で美泿客家語と似ているといえる。

このように方言間の関連性も見られるため、美浱客家語、北京語以外の 漢語諸方言についてもさらに研究を進めて行くことを今後の課題としたい。

\section{〈注〉}

1）本稿では北京城内に住む老年層が使う方言という狭い意味ではなく、いゆる 普通話を含めた広い意味で使う。

2）この詥文で使う表記は次のとおりである。子音（章韻尾を含む）：b [p], p[p $\left.\mathrm{p}^{\mathrm{n}}\right]$, $d[t], t\left[t^{h}\right], g[k], k\left[k^{h}\right], m[m], n[n], n g[n]\left([n] / \_i\right), f[\phi], v[\beta], s[s]([c] / / i), h[h]\left([c] / \_i\right), z[t s]$ $\left([t c] / \_i\right), c\left[t s^{n}\right],\left(\left[t c^{h}\right] / / i\right), 1[1]$ 。母音:単母音a, o, e, i, ii[1],uと複母音ai, au, ua, uai, ia, iau, iai, eu, ue, ie, ieu, oi, uoi, io, ioi, iu, ui, がある。また、声調は 6 種類あり、うち 5、6は閉音節 (いわゆる入声)。以下に各調值を示す。1 (陰平)：24 33、2 (陽 平)：11、3 (上声) : 42、4 (去声) :55、5 (陰入) : 32、6 (陽入) :5。本文中で

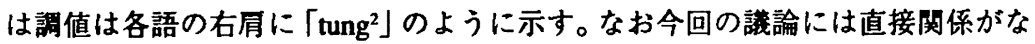
いため、変調する場合も本来の声調で示すことにする。

3）漢字表記については基本的に「㗌灣客家話鿷典」を参考にした。この辞春に挙 げられていない字、また挙げられていてもワープロソフトの問題で文字が出せな い字は口で表す。

4）上記の例は、田中智子 1999「現代中国語の「给」について」東京大学大学院 人文社会系研究科修士詥文（未公刊）による。

5) 王朔の作品 6 編（《给我顶住》《动物凶猛》《浮出海面》《过把看就死》《一半是 火焰一半是海水》《空中小姐》、合計約 271,000 字) を調べたところく(NP)给 NP $\mathrm{VP}>$ という構文は 230 例あった。そのうち使役を表していると考えられるもの が 28 例あり、使われている動詞のうちわけは、“看” 15 例、“吃”3例、“听” 2 例、“喝” 1 例、“跑” 2 例（ただし 1 例は受動文ともとれるもの）、“戴上” 1 例、 “吸(烟)" 1 例、“抽(姻)” 1 例、“感觉” 1 例、“做” 1 例、である。

6）美浱客家語では動詞「siit 」も「飲む」という意味を表す。しかし「食べる」と いう意味の動詞と同じ形式になるため、ここでは別の動詞「lim'」を使った例を 
挙げた。

7）これまでの調査では、名詞句の存在棁態の遗い（事前に存在するかしないか、 事前の所属先はどこか）は介詞の使い分けには反映していないようである。

\section{<用例出典>}

本稿で取り上げた客家語美湠方言の例は、筆者が 2000 年から 2003 年の間に行 なった現地調查で得たデータに基づく。特に明記しない場合は、鍾沐卿氏（76藏） の対面調查から得られたデータである。鍾氏は祖父の代から美浱鎮能肚里在住で、 元小学校教師である。日常語は客家語であるが、日本語や北京語も堪能である。な お 2004 年 6 月に行なった現地調査で、美暴在住・出身の 80 代 1 名と 30 代 2 名の 方に例文の校訂をお願いした。

第 6 節に挙げた小説のデータの出典は、“亦凡公益图书馆 http://www.shuku.net/” である。

\section{<参照文献>}

Comrie, Bernard 1989. Language Universals and Linguistic Typology (2nd ed.).Chicago:

Chicago University Press.

Li, Charles N. and Sandra A. Thompson 1976. Development of The Causative in Mandarin

Chinese: Interaction of Diachronic Processes in Syntax In Masayoshi Shibatani (ed.), The grammar of causative constructions (syntax and Semantics Vol.6) pp.477-492. New York: Academic Press.

刘丹青 2003. 「语法化中的共性与个性, 单向性与双向性」, 吴福样、洪波主编「语 法化与语法研究(一)」。北京：商务印书馆, 125-144 頁。

益岡隆志 2001.「日本語における授受動詞と恩患性」、「月刊言語」30巻5号, 26-32 頁。

奥津敬一郎, 徐昌華 1982. 「「てもらう」とそれに対応する中国語表現」,「日本語教 育」 46 号, 92-104頁。

佐々木幋人 2002.「中国語における使役と受益一比较方言文法の観点から一」, 筑波大学現代言語学研究会 (編)「事象と言語形式」。東京：三修 社, 177-197頁。

Shibatani, Masayoshi 1976. The grammar of causative constructions: a conspectus. In Masayoshi Shibatani (ed.), The Grammar of Causative Constructions (Syntax and Semantics Vol.6). pp.1-40 New York: Academic Press. 柴谷方良 1982.「日本語、英語」。森岡健二, 宮地裕, 寺村秀夫, 川端善明編「請座 日本語学」 10 外国語との対照 I：256-279頁。東京：明治筸院。 
Shibatani, Masayoshi and Prashant Pardeshi 2002. The causative continuum In Shibatani, Masayoshi (ed.), The Grammar of Causation and Interpersonal Manipulation (Typological Studies in Language v.48). pp.85-126 Amsterdam and Philadelphia: John Benjamins

Song, Jae Jung 2001. Linguistic Typology: Morphology and Syntax. Harlow and London: Pearson Education.

田中智子 2001a.「「给」使役文について」，「言語情報科学研究」6 号, 135-156 頁。 田中智子 2001b.「客家語の介詞「同」について」「日本中国語学会第 51 回全国大会 予稿集」, 85-89頁。

楊 凱栄 1989.「日本語と中国語の使役表現に関寸る対照研究」。東京：くろしお出 版。

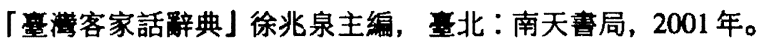

$$
\text { <付記> }
$$

2004 年 6 月には財団法人交流協会日台交流センター歷史研究者派遗事業の支援 を得て、例文等に関する確認調査を行なうことができた。なお、本稿を執筆するに 当たり、こ指導いただいたラマール・クリスティーン先生をはじめ、貫重なコメン トをいただいた方々に心より感碀申し上げます。 